\title{
Peningkatan Pemahaman tentang Komitmen Melayani Karyawan Gereja-gereja Kristen Jawa (GKJ) Klasis Jakarta Bagian Timur
}

\author{
Desi Sianipar ${ }^{1}$, Wahyu A. Rini ${ }^{2}$, Demsy Jura ${ }^{3}$ \\ 1,2,3 Universitas Kristen Indonesia, Jakarta, Indonesia \\ Desi.sianipar@uki.ac.id; wahyuarini@yahoo.com; demsy.jura@uki.ac.id
}

\begin{abstract}
Abstrak
Karyawan yang bekerja di gereja perlu mendapatkan pembinaan secara berkala, khususnya menyangkut komitmen mereka dalam melayani di lingkungan gereja. Dengan adanya pembinaan mengenai hal ini, semangat dan produktivitas mereka dapat ditingkatkan. Untuk itu, kegiatan Pengabdian kepada Masyarakat $(\mathrm{PkM})$ ini bertujuan untuk memberikan pengetahuan tentang komitmen melayani berdasarkan ajaran dalam Alkitab pada karyawan Kristen di lingkungan Gerejagereja Kristen Jawa (GKJ) klasis Jakarta Bagian Timur. Metode yang digunakan adalah seminar dan kemudian dilanjutkan dengan tanya jawab dan diskusi. Hasil dari kegiatan ini adalah karyawan merasakan bahwa seminar ini sangat bermanfaat untuk meningkatkan pemahaman mereka mengenai makna komitmen melayani menurut iman Kristen, dan mereka termotivasi untuk melakukan pelayanan yang lebih baik lagi. Hal ini terlihat dari antusiasme mereka dalam sesi tanya jawab, diskusi, dan hasil angket yang mereka isi setelah selesai kegiatan pengabdian kepada masyarakat. Mereka juga mengusulkan supaya kegiatan pembinaan yang bertujuan meningkatkan komitmen mereka dalam melayani diadakan secara berkala oleh GKJ Klasis Jakarta Bagian Timur.

Kata Kunci: komitmen melayani

Abstract

The employees who work in the church need to get coaching regularly, especially regarding their commitment to serve in the church. By this coaching, their enthusiasm and productivity in working can be improved. For this reason, these community service activities aim to provide knowledge about commitment to serve based on Biblical teachings especially to the employees in the Javanese Christian Church (Gereja-gereja Kristen Jawa Klasis Jakarta Bagian Timur). The method used is seminar, question and answer, and discussion. The results of this program are that employees feel that this program is very useful to improve their understanding of commitment to serve according to the Christian faith. They were also motivated to do better service in the church. Their enthusiasm could be seen in the question and answer sessions, discussion, and the results of the questionnaire that they had filled out. They also proposed that this coaching activity like this could be held regularly by GKJ Klasis Jakarta Bagian Timur.
\end{abstract}

Key word: commitment to serve 


\section{PENDAHULUAN}

Setiap orang Kristen harus bekerja dengan komitmen yang penuh. Tanpa komitmen, hasil pekerjaan menjadi tidak efektif. Orang dapat masuk dalam lingkaran pekerjaan, tetapi tidak menghasilkan sesuatu yang bermakna besar, baik bagi dirinya maupun bagi organisasi yang dilayaninya. Karena itu, adalah penting bagi seorang karyawan untuk memahami apa itu komitmen, hubungannya dengan organisasi, dan kekuatan komitmen.

Secara leksikal, pengertian komitmen dalam bahasa Indonesia sangat singkat, yaitu: perjanjian (keterikatan) untuk melakukan kontrak (http://kbbi.web.id/komitmen).

Berdasarkan pengertian ini, tampak bahwa komitmen adalah suatu sikap dan tindakan sangat kuat yang menunjukkan keterikatan di antara dua pihak yang berjanji untuk melakukan sesuatu yang sudah disepakati bersama. Dalam kamus berbahasa Inggris, komitmen adalah "an agreement or pledge to do something in the future; something pledged; the state or an instance of being obligated or emotionally impelled; an act of commiting to a charge or trust" (https://www.merriamwebster.com/dictionary/commitment).
Dari arti kamus ini, dapat dipahami bahwa komitmen adalah kesepakatan atau janji untuk melakukan sesuatu di masa depan; sesuatu yang dijanjikan; keadaan yang diwajibkan atau didorong secara emosional; atau tindakan berkomitmen terhadap tuntutan atau kepercayaan. Komitmen ini ada pada diri seseorang ketika dia sungguh-sungguh memahami arti kehadirannya dalam suatu organisasi dan makna organisasi itu bagi dirinya.

Banyak hal yang menyebabkan komitmen melayani para karyawan tidak sebagaimana yang diharapkan. Hal-hal tersebut antara lain adalah: kurangnya penyuluhan kepada para karyawan, kesenjangan hubungan pemimpin dan karyawan, kurangnya keterampilan dan kreativitas dalam bekerja, dan kurangnya penghargaan terhadap kinerja karyawan. Untuk itu, gereja perlu melakukan penyuluhan yang bersumber pada Alkitab, khususnya tentang peningkatan komitmen melayani pada karyawan GKJ Klasis Jakarta Bagian Timur. Hal ini perlu mendapat perhatian dari semua pimpinan GKJ dan setiap karyawan karena tanpa komitmen, kinerja mereka tidak akan optimal. Tujuan yang ingin dicapai dalam kegiatan ini adalah memberikan pemahaman dan 
penyadaran tentang pentingnya komitmen melayani pada setiap karyawan GKJ Klasis Jakarta Bagian Timur.

Ada beberapa manfaat yang diperoleh para karyawan dalam seminar ini, yaitu: Karyawan memiliki pemahaman yang benar mengenai komitmen pelayanan Kristen menurut ajaran dalam Alkitab. Karyawan juga memiliki kesadaran tentang pentingnya memiliki komitmen melayani yang benar sehingga kehadiran mereka menghasilkan halhal yang bermakna bagi lingkungan kerja mereka.

\section{METODE}

Metode yang digunakan dalam menyelesaikan masalah adalah dengan memberikan pendidikan masyarakat, berupa penyuluhan yang bertujuan meningkatkan pemahaman dan kesadaran mengenai pentingnya komitmen melayani para karyawan GKJ Klasis Jakarta Bagian Timur. Sebelumnya Tim PkM telah melakukan beberapa kali pertemuan dengan pihak mitra PkM, yaitu pengurus GKJ Klasis Jakarta Bagian Timur, dan mengadakan kerjasama secara formal. Kemudian Tim melakukan penyusunan materi seminar dan penetapan jadwal (dokumentasi pada gambar 1)

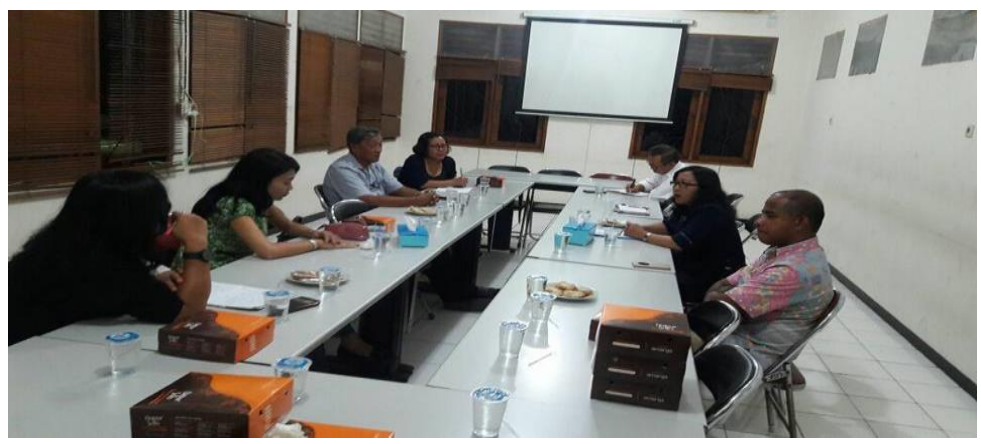

Gambar 1. Tim pada saat diskusi penyusunan materi sosialisasi

Kegiatan PkM ini dilaksanakan dalam bentuk seminar oleh Tim yang terdiri dari tiga dosen tetap Program Studi Magister Pendidikan Agama Kristen dengan dibantu oleh satu orang mahasiswa. Adapun peserta kegiatan ini adalah para karyawan GKJ, khususnya bagian administrasi dan keamanan di lingkungan Gereja- gereja Kristen Jawa Klasis Jakarta Bagian Timur yang berjumlah 40 orang. Setelah selesai kegiatan, Tim PkM membagikan angket kepada peserta yang isinya adalah penilaian peserta atas pelaksanaan kegiatan seminar dan harapan mereka selanjutnya. 


\section{HASIL DAN PEMBAHASAN}

Adapun hasil atau luaran dari pengabdian kepada masyarakat ini adalah berupa peningkatan pengetahuan dan kesadaran mengenai pentingnya komitmen melayani para karyawan GKJ Klasis Jakarta Bagian Timur. Ada tiga pokok bahasan yang disampaikan kepada mereka melalui seminar, tanya jawab, dan diskusi, yaitu: Prinsip Pelayanan di Gereja yang Sesuai dengan Firman Tuhan; Kekuatan Komitmen dalam Pelayanan Gereja; dan Pelayanan yang Bertanggungjawab.

Peserta yang hadir dalam kegiatan PkM berkisar adalah 40 orang. Kegiatan diadakan di GKJ Bekasi Timur. Keterbatasan waktu mengakibatkan tidak semua materi dan diskusi dapat disampaikan secara detail. Dilihat dari diskusi dan tanya jawab yang begitu antusias, maka dapat disimpulkan bahwa tujuan kegiatan ini dapat tercapai. Ketercapaian target materi pada kegiatan PkM ini cukup baik, karena materi penyuluhan telah dapat disampaikan secara keseluruhan. Penguasaan peserta akan materi masih kurang karena kemampuan para peserta dalam menangkap informasi adalah berbeda-beda.

Dalam seminar, Tim menyampaikan tiga hal yang harus diketahui oleh para karyawan, yaitu:

1. Bekerja adalah Pelayanan kepada Tuhan dan Sesama

Sebagai karyawan gereja, mereka harus memahami pengajaran dan teladan Tuhan Yesus dalam kitab Injil dan surat-surat Paulus yang menunjukkan bahwa pelayanan merupakan respon orang percaya kepada Tuhan. Respon itu terlihat melalui apa yang dikatakan dalam Yohanes 12:26: "Barangsiapa melayani Aku, ia harus mengikut Aku dan di mana Aku berada, di situ pun pelayan-Ku akan berada. Barangsiapa melayani Aku, ia akan dihormati Bapa". Melayani adalah sikap hidup yang bersedia memberi yang terbaik daripada menerima, dalam hal waktu, tenaga, dana dan lain-lain. Makna melayani dalam perspektif iman Kristen bersumber dari perkataan dan sikap pelayanan Yesus sebagaimana yang dikatakanNya: "sama seperti Anak Manusia datang bukan untuk dilayani, melainkan untuk melayani" (Mat. 20:28, Mrk. 10:45, dan Luk. 22:24-27). Kutipan tersebut menegaskan bahwa melayani merupakan kewajiban bagi setiap pengikut Kristus. Pelayanan yang sehat adalah pelayanan yang benar, tidak bercela, dan sesuai dengan kebenaran Injil, artinya bebas dari segala sesuatu yang dapat menimbulkan tuduhan. Melayani Tuhan meliputi pelayanan di hadapan publik, seperti: berkhotbah dan mengajar, menyanyi, dan melayani yang sifatnya administratif dan operasional sesuai dengan kecakapannya.

Mengenai kualitas pelayanan, Charles R. Swindoll mengemukakan bahwa dalam Titus 2:8, Paulus berbicara tentang ciri-ciri kualitas pelayanan, yaitu: pelayanan yang sehat, pelayanan yang tidak bercela, dan pelayanan yang berindikasi baik. Kualitas seorang pelayan hanya didapatkan ketika bersama-sama dengan Yesus dalam mengerjakan tugas tersebut. Kualitas seorang pelayan dapat terwujud dengan belajar kepada Yesus yang lemah lembut dan rendah hati (Mat. 11:2930): "Pikullah kuk yang Kupasang dan belajarlah pada-Ku, karena Aku lemah lembut dan rendah hati dan jiwamu akan mendapat ketenangan. Sebab kuk yang Kupasang itu enak dan 
beban-Ku pun ringan". Ketika pelayan Tuhan memiliki hati pelayan, ia akan mengagungkan Tuhannya (Charles $R$. Swindoll, 2011, 23). Di dalam Kolose 3:23 dikatakan bahwa "Apa pun juga yang kamu perbuat, perbuatlah dengan segenap hatimu seperti untuk Tuhan dan bukan untuk manusia."

Bekerja di gereja adalah salah satu bentuk pelayanan kepada Kristus. Bila orang bekerja di gereja, maka dia harus memahami makna kehadirannya di dalam gereja. Dia harus memahami bahwa gereja merupakan perkumpulan atau orangorang yang dipanggil keluar (Kol. 1:13; 2 Kor. 6:17,18). Gereja harus membawa umat manusia untuk berkumpul bersama sebagai keluarga Allah, yang menekankan adanya hubungan di antara anggota tubuh (Rm. 12:4,5; 1 Kor. 12:12). Sama seperti tubuh secara fisik, gereja memiliki fungsi tertentu untuk dilaksanakan. Gereja adalah tubuh Kristus. Efesus 1:22-23 menyatakan, "Dan segala sesuatu telah diletakkanNya di bawah kaki Kristus dan Dia telah diberikan-Nya kepada jemaat sebagai Kepala dari segala yang ada. Jemaat yang adalah tubuh-Nya, yaitu kepenuhan Dia, yang memenuhi semua dan segala sesuatu." Berkhof $\mathrm{H}$, Enklaar menyatakan bahwa tugas utama Gereja adalah melaksanakan Amanat Agung (Mandat Penginjilan) dan Mandat Budaya (Berkhof $\mathrm{H}$, Enklaar, 2009, 7). Mandat penginjilan terlihat jelas di dalam Amanat Agung di dalam Matius 28:19-20, "Karena itu pergilah, jadikanlah semua bangsa murid-Ku dan baptislah mereka dalam nama Bapa dan Anak dan Roh Kudus, dan ajarlah mereka melakukan segala sesuatu yang telah Kuperintahkan kepadamu. Dan ketahuilah, Aku menyertai kamu senantiasa sampai kepada akhir zaman." Penginjilan sejati harus mencakup dua aspek: verbal dan perbuatan. Gereja sesuai dengan
Amanat Agung Tuhan yang tertera di Matius 28:19-20 merupakan wakil Kerajaan Allah di dunia ini dan diperintahkan untuk membawa berita Injil untuk semua manusia di bumi. Gereja sebagai lembaga yang mengantarkan anak-anak untuk menjadi anggota, umat yang beriman, serta anak-anak Allah. Gereja memberikan peluang dan melatih jemaat untuk bertumbuh dalam disiplin rohani, yakni kehidupan berdoa dan berpuasa, waktu teduh pribadi, bersaksi bagi Tuhan. Tugas Gereja dalam mandat budaya adalah untuk menaklukkan dan memelihara serta mengembalikan alam ciptaanNya itu untuk kemuliaan Tuhan, sesuai Firman Tuhan: "Allah memberkati mereka, lalu Allah berfirman kepada mereka: "Beranakcuculah dan bertambah banyak; penuhilah bumi dan taklukkanlah itu, berkuasalah atas ikan-ikan di laut dan burung-burung di udara dan atas segala binatang yang merayap di bumi" (Kej. 1:28). Tuhan memerintahkan manusia untuk menguasai dan memelihara alam ciptaan-Nya untuk dipergunakan memuliakan-Nya selama-lamanya (Kej. 2:15).

Ada tiga tugas gereja yang harus dipahami oleh para karyawan gereja yang berguna untuk memotivasi mereka bekerja dengan benar di dalam gereja. Tiga tugas gereja tersebut adalah: koinonia, marturia dan diakonia. Koinonia (bersekutu, 1 Kor. 12:26). Persekutuan itu dialaskan atas dasar Firman Allah, Baptisan dan Perjamuan Kudus. Koinonia (Yunani, koıvwvía) adalah persekutuan dengan partisipasi intim. Persekutuan dalam kasih ini meliputi keramahan (lbr. 13:2); tolong menolong dalam menanggung beban (Gal. 6:2); saling memberi semangat (lbr. 10:25) dan saling mendoakan (Flp. 1:9,11,19) (Krido Siswanto, 2014, 97). Marturia 
berarti kesaksian, pembelaan. Pada masa kini, marturia biasa dipakai untuk menunjuk pada tugas gereja dalam menyaksikan kasih Kristus kepada dunia (Krido Siswanto, 2014, 98). Diakonia (melayani) artinya memberi pertolongan atau pelayanan. Dalam Perjanjian Baru, diakonia dipahami bukan hanya dalam arti pelayanan hamba kepada tuannya saja, tetapi juga pelayanan tuan kepada hambanya dan pelayanan antar sesama (bnd. Mat. 4:11; Mrk. 1:31; Luk. 10:40, 12:37; Yoh. 2:5) (https://hesron89.wordpress.com/201 3/05/03/gereja-dan-diakonia). Gereja dalam memenuhi tugas dan panggilannya dalam masyarakat harus meresponi kebutuhankebutuhan sosial masyarakat, termasuk gereja harus memiliki kepedulian terhadap masyarakat yang miskin.

Atas dasar penjelasan mengenai apa itu gereja dan tugasnya di dalam dunia yang diperolehnya dari Tuhan, maka seorang karyawan gereja adalah pelayan yang dipanggil dan dilibatkan Tuhan untuk melaksanakan tugas-tugas panggilan gereja. Pekerjaan itu sangat besar dan mulia sehingga tidak bisa dihargai dengan hal-hal materi. Nilai pekerjaan itu bernilai melampaui nilai-nilai material. Karena itu adalah suatu kebanggaan bila terlibat dalam pekerjaan gerejawi.

\section{Pekerja Gereja Harus Memiliki} Komitmen Penuh dalam Pelayanan

Setiap orang yang bekerja di dalam suatu organisasi tentu memiliki tujuan dan harapan. Hal itulah yang memotivasi seseorang berada dalam suatu organisasi. Alkitab memberi gambaran tentang komitmen melalui keteladan Yesus Kristus. Ada pernyataan Yesus dalam Alkitab yang berhubungan dengan komitmen, yaitu antara lain: a. Kesetiaan kepada Tuhan (Mat. 6:24; Yak. 4:4)

Yesus mengajar orang Kristen untuk setia hanya kepada Tuhan. Sifat yang melekat pada diri manusia adalah tidak bisa memiliki dua komitmen sekaligus yang bertentangan satu sama lain. Dia pasti akan setia pada yang satu, dan akan mengabaikan yang lain. Manusia tidak bisa berkomitmen kepada Allah dan kepada harta dunia atau berhala atau Iblis, dua hal yang berlawanan, sebagaimana yang dinyatakan dalam kedua ayat ini:

"Tak seorangpun dapat mengabdi kepada dua tuan. Karena jika demikian, ia akan membenci yang seorang dan mengasihi yang lain, atau ia akan setia kepada yang seorang dan tidak mengindahkan yang lain. Kamu tidak dapat mengabdi kepada Allah dan kepada Mamon" (Mat. 6:24).

"Hai kamu, orang-orang yang tidak setia! Tidakkah kamu tahu, bahwa persahabatan dengan dunia adalah permusuhan dengan Allah? Jadi barangsiapa hendak menjadi sahabat dunia ini, ia menjadikan dirinya musuh Allah" (Yak. 4:4).

Karyawan yang setia atau berkomitmen kepada organisasi, misalnya gereja, bukanlah komitmen buta, tetapi ukuran komitmen yang benar adalah komitmen kepada Tuhan. Meskipun dia memiliki kebutuhan hidup berupa materi, promosi, peningkatan kualitas kinerja, dsb., yang dia inginkan atau harapkan dari suatu organisasi, tetapi itu 
bukanlah motivasi yang tertinggi. Motivasi tertinggi berasal dari komitmennya kepada Tuhan dan pelayanan-Nya. Itu sebabnya, ketika memutuskan untuk berkomitmen pada sesuatu atau ingin meninggalkan sesuatu, orang Kristen memiliki pola, yaitu meminta petunjuk kepada Tuhan melalui doa. Ketika berhadapan dengan pilihan yang amat sulit, seorang karyawan Kristen harus membawa pergumulannya kepada Tuhan. Hal ini tampak dalam teladan Kristus dan teladan orang-orang percaya dalam Alkitab.

"Namun mezbah tembaga yang dibuat Bezaleel bin Uri bin Hur masih ada di sana di depan Kemah Suci TUHAN. Maka ke sanalah Salomo dan jemaah itu meminta petunjuk TUHAN' (2 Taw. 1:5).

"Janganlah hendaknya kamu kuatir tentang apapun juga, tetapi nyatakanlah dalam segala hal keinginanmu kepada Allah dalam doa dan permohonan dengan ucapan syukur. ..." (Flp. $4: 6)$.

b. Komitmen Didasarkan pada Panggilan Tuhan

Ketika seorang karyawan berkomitmen pada sesuatu yang menjadi pilihannya, haruslah didasarkan pada panggilan Tuhan yang jelas dalam hidupnya. Bila tidak, dia tidak akan memiliki rasa yakin dengan apa yang dia kerjakan. Panggilan Allah yang jelas dalam hidup seseorang akan membuat dia berkonsentrasi dan bersukacita dalam melakukan pekerjaannya. Ukuran sukses bukan lagi ditentukan oleh seberapa besar materi atau pencapaian lain yang berhasil dikumpulkannya. Dia tidak akan mudah terganggu atau gelisah dengan ukuran kesuksesan yang dimiliki oleh orang lain. Dia tidak akan cemburu atau iri hati dengan apa yang diperoleh orang lain. Orang mustahil bisa memiliki komitmen penuh pada sesuatu atau organisasi kalau tidak didasarkan pada panggilan Tuhan. Karena itu, orang Kristen harus memahami panggilan Tuhan dalam hidupnya dan menyambutnya dengan penuh sukacita lewat karya-karya yang optimal. Berdasarkan panggilan Tuhan, maka tampaklah ciri-ciri dari orang yang berkomitmen sebagaimana yang diungkapkan oleh Ashish Raichur:

- Bersedia membayar harga apapun (berkorban) dalam pekerjaannya. Dia akan bersedia untuk bekerja keras untuk mencapai sasaran-sasaran yang telah ditetapkan organisasi karena dia menyadari bahwa apa yang dikerjakannya adalah bagian dari rencana dan pekerjaan Tuhan (Why. 12:11).

- Bersedia mengatasi semua rintangan dalam pekerjaannya. Orang seperti ini tidak mudah menyerah atau tidak mudah berhenti dari suatu pekerjaan demi menjaga komitmennya. Orang bisa saja melakukan pekerjaannya selama bertahuntahun, tetapi sesungguhnya bukan karena komitmennya, tetapi karena segala yang diinginkannya masih tersedia. Orang yang berkomitmen adalah orang yang mampu tetap fokus pada komitmennya dan tidak mudah terganggu oleh apapun di sekitarnya. Yesus memberi gambaran tentang hal ini dalam Lukas 9:57-62 (Ashish Raichur, 
2005, 3-4).

c. Berkomitmen Harus Sepadan dengan Kemampuannya

Berkomitmen pada sesuatu

hal, orang, atau organisasi harus sesuai dengan ukuran kemampuan yang dimiliki. Karena itu, seorang karyawan yang menyatakan komitmennya, harus mempertimbangkannya dengan sangat baik, mendoakannya dengan sungguh-sungguh, dan jangan memutuskan sesuatu dengan emosional. Komitmen yang penuh tentu menunjukkan kinerja yang baik yang disertai dengan hasil yang sepadan karena orang bekerja pada bidang yang sesuai dengan kemampuannya, dan dia bersukacita melakukannya.

"Berdasarkan kasih karunia yang dianugerahkan kepadaku, aku berkata kepada setiap orang di antara kamu: Janganlah kamu memikirkan hal-hal yang lebih tinggi dari pada yang patut kamu pikirkan, tetapi hendaklah kamu berpikir begitu rupa, sehingga kamu menguasai diri menurut ukuran iman, yang dikaruniakan Allah kepada kamu masing-masing." (Rm. 12:3).

"Sebab siapakah di antara kamu yang kalau mau mendirikan sebuah menara tidak duduk dahulu membuat anggaran biayanya, kalau-kalau cukup uangnya untuk menyelesaikan pekerjaan itu?" (Luk. 14:28).

Orang Kristen harus tetap menjaga komitmennya karena hal itu memiliki kekuatan bagi hidup dan karyanya. Ashish Raichur menyatakan ada empat hal yang diperoleh seseorang dari komitmennya, yaitu: (1) kekuatan, stabilitas, dan kepastian; (2) berkatberkat; (3) upah; (4) kemajuan (1 Tim. 4:15) (Ashish Raichur, 2005, 6-8). Contoh dalam Alkitab mengenai komitmen yang telah menghasilkan kekuatan, stabilitas, dan kepastian, berkat-berkat, upah, dan kemajuan adalah komitmen Ruth untuk mengikuti Tuhan yang disembah oleh Naomi.

"Tetapi kata Rut: "Janganlah desak aku meninggalkan engkau dan pulang dengan tidak mengikuti engkau; sebab ke mana engkau pergi, ke situ jugalah aku pergi, dan di mana engkau bermalam, di situ jugalah aku bermalam: bangsamulah bangsaku dan Allahmulah Allahku; di mana engkau mati, akupun mati di sana, dan di sanalah aku dikuburkan. Beginilah kiranya TUHAN menghukum aku, bahkan lebih lagi dari pada itu, jikalau sesuatu apapun memisahkan aku dari engkau, selain dari pada maut!" (Ruth 1:16-17).

Jika menggali lebih mendalam, maka dalam Alkitab akan muncul 203 kali kata ibadah, dan untuk kata yang berkaitan dengan kerja, muncul sebanyak 533 kali. Artinya kata kerja lebih banyak dicantumkan dalam Alkitab, melebihi kata ibadah. Bahkan kata kerja lebih dahulu muncul daripada kata ibadah. Kata kerja untuk pertama kali muncul dalam kitab Kejadian 2:2, sedangkan kata ibadah baru muncul untuk pertama kalinya pada kitab Kejadian 3:12 (Sulastro Wirawan, 2014, 67). Pekerjaan yang dilakukannya haruslah dikerjakan dengan sungguh- 
sungguh dan optimal. Alkitab mengajarkan hal yang sederhana dalam dunia kerja, yaitu: "Apa pun juga yang kamu perbuat, perbuatlah dengan segenap hatimu seperti untuk Tuhan dan bukan untuk manusia." (Kol. 3:23), dan Tuhan Yesus pernah berkata: “... Bapa-Ku bekerja sampai sekarang, maka Aku pun bekerja juga" (Yoh. 5:17). Kerja adalah hal yang tidak terpisahkan dalam kehidupan setiap orang sebagaimana yang dikatakan rasul Paulus: "Baiklah tiap-tiap orang menguji pekerjaannya sendiri; maka ia boleh bermegah melihat keadaannya sendiri dan bukan melihat keadaan orang lain" (Gal. 6:4), dan kata ergo (ع̌pyo) yang menunjuk kepada pekerjaan (work), yang berarti: bisnis, usaha, yang dilakukan seseorang; suatu produk apapun yang dikerjakan oleh tangan, seni, industri atau pikiran atau suatu tindakan atau perbuatan atau sesuatu yang dilakukan (Sulastro Wirawan, 2014, 38).

Karyawan yang melayani di gereja adalah seorang pekerja, dan untuk itu, dia seharusnya mendapatkan upahnya. Apa yang dipeolehnya bukanlah sebuah bentuk belas kasihan orang atas dirinya, melainkan karena hak yang dia miliki sebagai seorang pekerja, sebagaimana yang dikatakan dalam Alkitab: Kalau ada orang yang bekerja, upahnya tidak diperhitungkan sebagai hadiah, tetapi sebagai haknya (Rm. 4:4). Itulah sebabnya seseorang berhak atas upah kerja yang dia terima dan hal itu menjadi haknya, namun demikian terkadang beberapa orang tidak mampu menunjukkan pola kerja yang baik. Seorang pekerja harus mampu menunjukkan sikap kerja yang baik supaya dia tidak salah dalam menjalani tugas kerjanya.

Ada tiga hal yang menjadi alasan mengapa orang harus bekerja, yaitu: Pertama, bekerjalah untuk kemuliaan nama Tuhan. Seorang Kristen haruslah menyadari prinsip penting ini dalam dunia pekerjaan. Hal apapun dalam kehidupan ini seharusnya untuk kemuliaan nama Tuhan, dan hal itu tidak lepas dalam dunia pekerjaan. Dengan tegas dikatakan bahwa: "Kita melakukan pekerjaan ... Aku menjawab: Jika engkau makan atau jika engkau minum, atau jika engkau melakukan sesuatu yang lain, lakukanlah semuanya itu untuk kemuliaan Allah." (1 Kor. 10:31). Ketika seseorang bekerja sebagai petugas kebersihan, dia dapat memuliakan nama Tuhan. Sebagai seorang pekerja Kristen, dia harus bekerja dengan penuh kesungguhan hati sehingga melalui hasil kerjanya, nama Tuhan dipermuliakan.

Kedua, rasul Paulus memberikan nasehat penting untuk para pekerja, yaitu: "Lakukanlah segala pekerjaanmu dalam kasih!" (1 Kor. 16:14). Dalam dunia kerja seringkali tuntutan atas suatu pekerjaan dapat menempatkan seseorang pada posisi yang tertekan sehingga tidak jarang menimbulkan masalah personal. Seorang pekerja harus mampu melaksanakan pekerjaannya dengan penuh kesungguhan hati, dan hanya dengan kasih maka seseorang akan dapat melaksanakan tugas dan tanggung jawab dengan baik. Bekerja dengan sungguh-sungguh akan menghasilkan hasil kerja yang memuaskan semua pihak, dan di atas segala-galanya, kasih menjadi nomor pertama. Jika tanpa kasih, maka suatu pekerjaan hanya dilaksanakan secara rutinitas dan monoton serta terpaksa dilakukan. Hati yang tidak tulus dan penuh sungut-sungut dalam bekerja tidak akan memberikan hasil yang optimal. Itulah sebabnya diperlukan kasih yang tulus dalam melakukan tugas pekerjaan. 
Ketiga, lakukanlah pekerjaan dengan penuh ucapan syukur. Hal apapun yang dikerjakan dalam dunia pekerjaan, haruslah dilaksanakan dengan penuh ucapan syukur. Tidak membantah ataupun mengerjakannya dengan setengah hati. Penegasan ini disampaikan dalam Kitab Suci, yaitu: "Dan segala sesuatu yang kamu lakukan dengan perkataan atau perbuatan, lakukanlah semuanya itu dalam nama Tuhan Yesus, sambil mengucap syukur oleh Dia kepada Allah, Bapa kita."(Kol. 3:17). Keterpaksaan dalam mengerjakan suatu perintah hanya akan memberikan hasil yang mengecewakan. Bekerja karena upah tidaklah salah, namun jika hal upah menjadi indikator utama, maka seorang Kristen hanya akan bekerja berdasarkan besaran upah yang dia terima.

Secara prinsip, bekerja itu sama dengan melayani. Apabila memperhatikan uraian sebelumnya, yaitu bahwa suatu pekerjaan harusnya untuk kemuliaan nama Tuhan (lih. 1 Kor. 10:31), dan bahwa pekerjaan itu harus dilakukan dengan penuh kasih serta suatu pekerjaan haruslah dilaksanakan dengan penuh ucapan syukur, maka dapatlah dikatakan bahwa bekerja itu sama dengan melayani. Setiap orang Kristen harus bekerja, namun pekerjaan yang dijalaninya jangan sampai mengorbankan dirinya dan juga orang lain. Bekerjalah dengan baik dan sesuai dengan prinsipprinsip Alkitab. Seorang pekerja Kristen harus mampu menunjukkan cara kerja yang bertanggungjawab. Alkitab memberikan perintah untuk menjalani dunia kerja dengan baik, yaitu: "Hai hamba-hamba, taatilah tuanmu yang di dunia ini dalam segala hal, jangan hanya di hadapan mereka saja untuk menyenangkan mereka, melainkan dengan tulus hati karena takut akan Tuhan." (Kol. 3:22).
Ada atasan, ada pimpinan yang kesemuanya harus diikuti dan bahkan ditaati. Dunia kerja tidak bisa dilepaskan dalam kaitan diri sebagai orang percaya, artinya setiap orang Kristen harus mampu memberikan kesaksian yang hidup dalam dunia kerja yang degelutinya.

Yakub memberikan contoh yang baik dalam dunia kerja, yaitu ketika ia dengan tegas dan berani mengungkapkan hal pekerjaan yang dikerjakannya, yaitu: Sahut Yakub kepadanya: "Engkau sendiri tahu, bagaimana aku bekerja padamu, dan bagaimana keadaan ternakmu dalam penjagaanku" (Kej. 30:29). Yakub menunjukkan kepada semua orang bahwa dia telah melakukan pekerjaannya dengan baik, dan bahkan kepada pemilik pekerjaan. Pekerjaan yang telah dilakukannya dapat dibuktikan dari hasil pekerjaan yang dicapai, yaitu: "bagaimana ternakmu dalam penjagaanku" (ay. 29). Artinya, kepercayaan dalam menjaga ternak telah dikerjakan dengan baik, dan ada hasilnya. Jika sudah melakukan tugas kerja dengan baik, maka tidaklah salah untuk menyatakan bahwa seseorang telah bekerja dengan baik. Perhatikanlah ayat Alkitab berikut ini: "Juga kamu sendiri tahu, bahwa aku telah bekerja sekuat-kuatku pada ayahmu.

Selama dua puluh tahun ini aku di rumahmu; aku telah bekerja padamu empat belas tahun lamanya untuk mendapat kedua anakmu dan enam tahun untuk mendapat ternakmu, dan engkau telah sepuluh kali mengubah upahku" (Kej. 31:6, 41). Kata "sekuatkuatku" dalam ayat 6 diterjemahkan dari kata koach (nַj), yaitu ability dan kata kol (כ), yaitu the whole, all, dengan pengertian yang sederhana, yaitu "dengan seluruh kemampuan", artinya pekerjaan yang dilakukan telah dikerjakan dengan seluruh kekuatan diri yang ada padanya. Inilah yang dimaksudkan dengan 
bekerja sebagaimana seharusnya orang percaya bekerja. Jadi benarlah pernyataan Kitab Suci berikut ini, yaitu: "Apa pun juga yang kamu perbuat, perbuatlah dengan segenap hatimu seperti untuk Tuhan dan bukan untuk manusia." (Kol. 3:23), dan pada akhirnya bekerja merupakan hal yang patut sebab mereka yang tidak bekerja, tidak Rangkaian kegiatan terdokumentasi dalam bentuk foto seperti dalam gambar 2 berikut. pantas untuk menikmati hasilnya, sebagaimana yang dinyatakan dalam nats Alkitab berikut ini, "Jika seorang tidak mau bekerja, janganlah ia makan" (2 Tes. 3:10b).

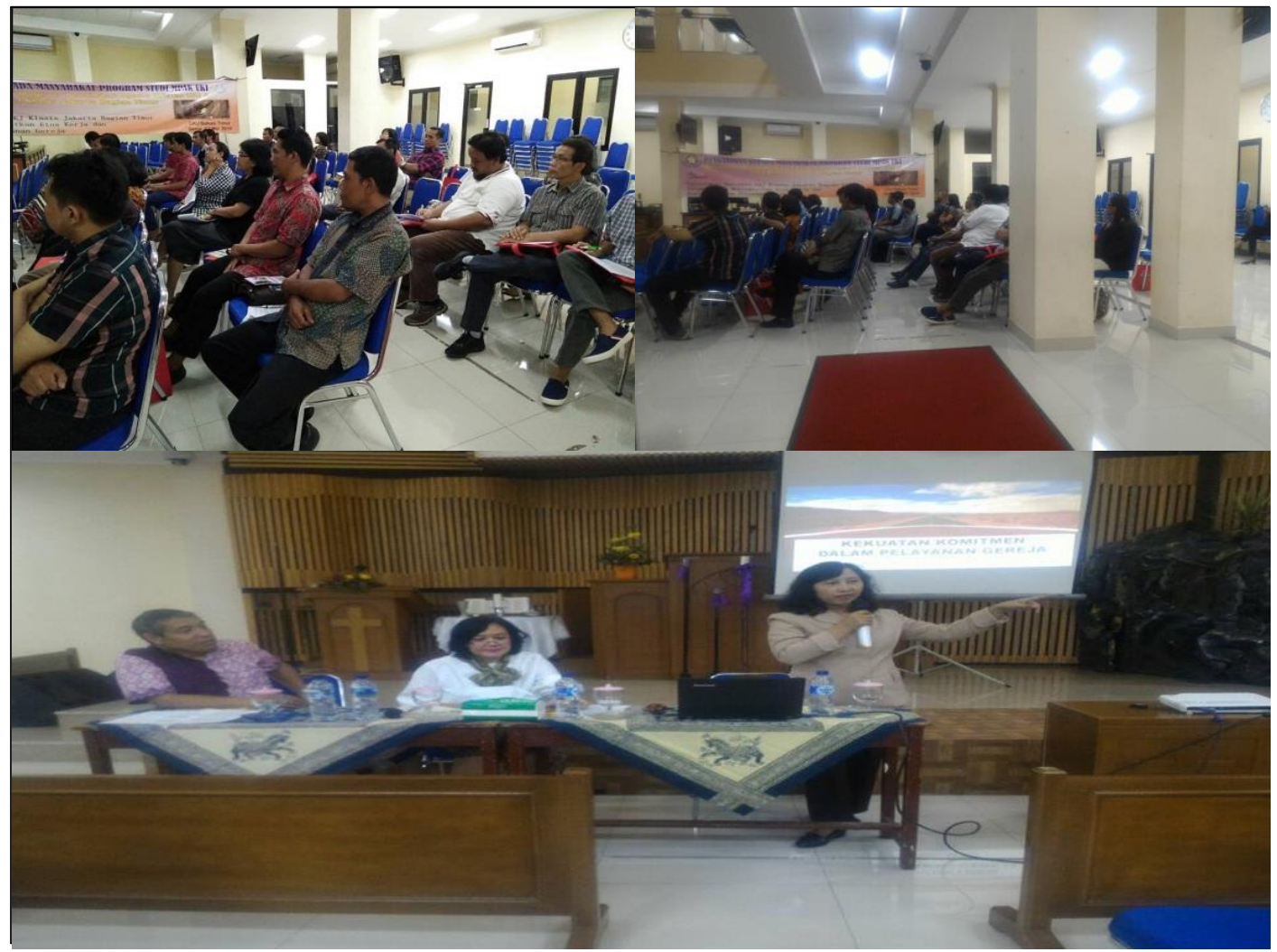

Gambar 2. Dokumentasi pada saat pemaparan

\section{SIMPULAN}

Penyuluhan berupa seminar tentang komitmen melayani pada karyawan GKJ Klasis Jakarta Bagian Timur dapat diselenggarakan dengan baik dan lancar sesuai dengan rencana kegiatan yang telah disusun meskipun masih ada beberapa kendala yang ditemukan dalam proses PkM ini. Kegiatan ini mendapat sambutan sangat baik terbukti dengan keaktifan peserta mengikuti penyuluhan dengan tidak meninggalkan tempat sebelum waktu berakhir. 
telah dilakukan dapat diajukan beberapa saran, yaitu: waktu pelaksanaan kegiatan pengabdian perlu ditambah agar tujuan kegiatan dapat tercapai sepenuhnya; dan adanya kegiatan lanjutan secara periodik sehingga para karyawan gereja dapat menjalankan perannya secara optimal. Berdasarkan angket yang diisi peserta setelah selesai kegiatan, mereka menginginkan agar pada waktu berikutnya, materi-materi yang disampaikan antara lain: Seminar untuk keluarga pekerja gereja; pelayanan terhadap non Kristen; seminar gabungan pekerja gereja dan majelis jemaat; sinergi semua pihak dalam gereja; cara menghadapi kebijakan dari majelis jemaat yang berbeda-beda; keterampilan untuk karyawan; cara mendapatkan penghasilan tambahan; dan cara ternak ikan lele.

\section{UCAPAN TERIMA KASIH}

Tim pengabdian kepada masyarakat berterimakasih kepada semua pihak yang terlibat dalam kegiatan ini. Pertama-tama kepada Badan Pelaksana Klasis XVI GKJ Kla sis Jakarta Bagian Timur dan Ketua Forum Komunikasi Karyawan Gereja se GKJ klasis Jakarta Bagian Timur yang telah mengundang Tim PkM dari Program Studi Magister Pendidikan Agama Kristen UKI dan memfasilitasi pelaksanaan kegiatan ini dengan menyediakan tempat dan konsumsi selama kegiatan berlangsung. Kedua, Tim juga berterima kasih kepada Rektor Universitas Kristen Indonesia yang telah memberi kesempatan dan mendukung dengan dana. Ucapan terima kasih juga disampaikan kepada semua peserta kegiatan yang berasal dari Gereja-gereja Klasis Jakarta Bagian Timur.

\section{REFERENSI}

Enklaar, Berkhof H. (2009 cet. ke-4). Sejarah gereja. Jakarta: BPK Gunung Mulia.

Raichur, Ashish (2005). The power of commitment. Bangalore: All People Church \& World Outreach.

Siswanto, Krido (2014), Tinjauan teoritis dan teologis terhadap diakonia transformatif gereja. Jurnal Simpson. ISSN: 23561904.

Swindoll, Charles R. (2011), Meningkatkan pelayanan anda: Improving your serve. Bandung: Pionir Jaya.

Wirawan, Sulastro (2014), Dunia kerja Kristen. Yogyakarta: Penerbit Iman.

http://kbbi.web.id/komitmen, diunduh 28 April 2018.

https://hesron89.wordpress.com/2013/ 05/03/gereja-dan-diakonia/, diunduh 28 April 2018.

https://www.merriamwebster.com/dictionary/commit ment, diunduh 28 April 2018 